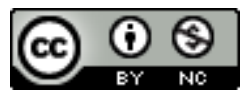

Jurnal Pendidikan Matematika Indonesia is licensed under

A Creative Commons Attribution-Non Commercial 4.0 International License.

\title{
Pengembangan Kemampuan Pemecahan Masalah Matematis Siswa Pada Materi Pertidaksamaan Linier Satu Variabel Melalui Model Problem Based Learning Berbantuan Modul
}

\author{
Mariyam $^{1)}$, Nindy Citroresmi $\mathrm{P}^{2}$, Rika Wahyuni ${ }^{3)}$ \\ 1) STKIP Singkawang, Singkawang, Indonesia \\ Email: mariyam.180488@gmail.com \\ 2) STKIP Singkawang, Singkawang, Indonesia \\ Email: nindy.citroresmi@gmail.com \\ ${ }^{3)}$ STKIP Singkawang, Singkawang, Indonesia \\ Email: rikawahyuni142@gmail.com
}

\begin{abstract}
Penelitian ini bertujuan untuk mengembangkan kemampuan pemecahan masalah matematis siswa pada materi Pertidaksamaan Linear Satu Variabel (PtLSV) melalui penerapan model Problem Based Learning (PBL) berbantuan modul. Metode penelitian yang digunakan dalam penelitian ini adalah penelitina dan pengembangan (research and development) yang direkomendasikan oleh Borg \& Gall yang dimodifikasi dengan model ADDIE yang memiliki lima fase utama yaitu Analysis, Design, Development, Implementation, dan Evaluation. Selanjutnya pada tahap Implementation digunakan metode eksperimen dengan rancangan penelitian Pretest-Posttest Control Group Design.Populasi dalam Penelitian ini adalah semua siswa Kelas VII SMP N 2 dan SMP N 7 Singkawang. Sampel dipilih dengan teknik simple random sampling. Hasil analisis data menunjukkan bahwa; (1) Modul berbasis masalah dan RPP yang dikembangkan layak digunakan untuk mengembangkan kemampuan pemecahan masalah matematis siswa, karena telah memenuhi kriteria valid, praktis dan efektif; (2)Tidak terdapat perbedaan peningkatan kemampuan pemecahan masalah matematis siswa pada materi PtLSV antara kelas yang menggunakan model PBL dan kelas yang menggunakan model pembelajaran langsung dengan pendekatan saintifik berbantuan modul di SMP Negeri 2 Singkawang; (3) Tidak Terdapat perbedaan peningkatan kemampuan pemecahan masalah matematis siswa pada materi PtLSV antara kelas yang menggunakan model PBL dan kelas yang menggunakan model pembelajaran langsung dengan pendekatan saintifik berbantuan modul di SMP Negeri 7 Singkawang.
\end{abstract}

Kata Kunci: Problem Based Learning, Pemecahan Masalah Matematis, Modul Berbasis Masalah

\section{PENDAhUluan}

Dalam pembelajaran matematika, diperlukan beberapa keterampilan agar siswa dapat memahami materi, lancar menggunakan dan melakukan proedur sehingga mampu menyelesaikan masalah dengan tepat dan benar. Keterampilan yang dimaksud adalah kemampuan melakukan proses dalam memahami isi dari materi matematika untuk menghasilkan keahlian dalam matematika. Adapun menurut National of Caountil Teacher of Mathematical (NCTM) standar proses dalam matematika meliputi pemecahan masalah (problem solving), penalaran dan pembuktian (reasoning and proof), keterkaitan (connections), komunikasi (communication) dan representasi (representation). Proses ini dilakukan agar siswa memiliki kemampuan pemahaman konsep, kelancaran prosedur dan pemecahan masalah. Dari penjelasan tersebut ada sesuatu yang khusus yaitu kemampuan pemecahan masalah tidak hanya sebatas hasil atau kemampuan yang diharapkan muncul dalam diri siswa, melainkan proses yang harus ada jika mengharapkan siswa terampil memecahkan masalah. Sehingga dapat diambil kesimpulan bahwa dalam pembelajaran siswa harus dilatih dan dibiasakan dalam memecahkan suatu masalah melalui tahapan-tahapan tertentu. 


\section{A - - - Jurnal Pendidikan Matematika Indonesia \\ Volum 3 Nomor 2 bulan September 2018 Page 66 - 73 \\ p-ISSN: 2477-5967 e-ISSN: 2477-8443}

Tahapan pemecahan masalah merupakan suatu proses yang kompleks karena di dalam menyelesaikan masalah menuntut siswa mengkoordinasikan antara pengalaman, pengetahuan, dan pemahaman mereka dalam menyelesaikan suatu permasalahan yang dimulai dari mengenal masalah tersebut sampai pada membuktikan kebenaran dari solusi yang dihasilkan. Polya (dalam Sumarmo, 2014) menyebutkan bahwa siswa dikatakan memiliki kemampuan pemecahan masalah, jika siswa tersebut mampu; memahami masalah (mampu mengidentifikasi masalah yang ada dalam suatu permasalahan, dapat mengetahui hal-hal apa yang diketahui dalam suatu permasalahan), menyusun rencana (membuat rencana atau strategi penyelesaian yang benar dan mengarah pada jawaban yang benar), melaksanakan penyelesaian (melakukan prosedur yang benar dan mendapat hasil yang benar), memeriksa kembali (memeriksa kebenaran dari keseluruhan proses yang telah dilakukan). Maka dari itu, jika siswa memiliki kemampuan tersebut maka siswa akan dengan mudah menguasai keterampilan lainnya. Hal ini dikarenakan menurut Gagne pemecahan masalah merupakan satu di antara keterampilan intelektual yang lebih tinggi derajatnya dan lebih kompleks dari tipe keterampilan intelektual lainnya (Badu, 2014).

Namun, Hasil PISA 2015 menunjukkan bahwa skor rata-rata siswa sebesar 386 dan Indonesia berada pada peringkat ke-63 dari 70 negara peserta (OECD, 2016). Selanjutnya berdasarkan hasil Trends in International Mathematics and Science Study (TIMSS) 2011 kemampuan matematika siswa SMP Indonesia berada pada peringkat ke-38 dari 42 negara.

Pertidaksamaan linear satu variabel (PtLSV) merupakan satu diantara materi penting dikarenakan konsep dari materi ini menjadi salah satu dasar untuk memahami materi pada jenjang berikutnya yang lebih tinggi, sehingga siswa dituntut untuk menguasai konsep dalam materi ini. Namun pada aplikasinya siswa kurang paham bahkan cenderung keliru ketika diminta untuk menyatakan model matematika dari suatu permasalahan yang berkaitan dengan PtLSV. Selain itu, fakta yang terjadi adalah kesulitan siswa dalam memahami materi matematika karena kemampuan bernalarnya belum berkembang dengan baik, hal ini disebabkan oleh proses pembelajaran yang tidak mendukung atau memfasilitasi berkembangnya kemampuan tersebut (Mariyam dan Wahyuni, 2016:75).

Berdasarkan uraian masalah di atas, maka diperlukan suatu cara mengelola dan menanamkan belajar pemecahan masalah bagi siswa dengan membuat siswa terbiasa mengerjakan soal-soal yang menantang dan soal-soal non rutin. Beberapa cara diantaranya adalah dengan mengembangkan bahan ajar dan menggunakan strategi pembelajaran yang mendukung berkembangnya kemampuan pemecahan masalah siswa.berkaitan dengan bahan ajar, salah satu bentuknya dapat berupa modul. Modul adalah bahan belajar mandiri yang dikemas secara sistematis dan terarah yang berisi seperangkat pengelaman belajar yang tererncana agar siswa dapat belajar secara mandiri dengan atau tanpa bimbingan guru (Daryanto (2013), Hamdani (2011), Majid (2011), Mulyasa (2011)). Agar dapat mengembangkan kemampuan pemecahan masalah siswa, maka modul yang digunakan hendaknya berbasis pada masalah yang memuat permasalahan matematika yang tidak hanya dikerjakan dengan prosedur rutin.

Namun penggunaan modul sebagai pendamping pembelajaran di sekolah dinilai masih kurang memenuhi kebutuhan siswa untuk mencapai tujuan pembelajaran matematika yang optimal. Hasil studi pendahuluan Citroresmi (2016: 4) menemukan bahwa modul yang digunakan siswa belum bisa menyediakan ilustrasi ataupun permasalahan dalam kehidupan sehari hari, materi modul hanya berupa ringkasan materi yang tidak cukup sebagai bahan referensi pembelajaran matemtaika, sedangkan siswa memerlukan pemaparan materi yang memungkinkan mencapai tujuan pembelajaran. Penggunaan modul perlu didukung oleh strategi pembelajaran yang sesuai dan dapat mengembangkan kemampuan pemecahan matematis siswa. Salah satunya adalah model problem based learning (PBL) yang merupakan suatu model pembelajaran yang menggunakan masalah kontekstual sebagai dasar bagi siswa untuk belajar berfikir tentang pemecahan masalah (Scolatika,dkk, 2014). 


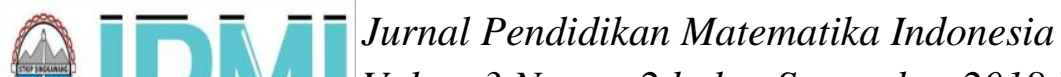 \\ Volum 3 Nomor 2 bulan September 2018 Page 66 - 73 \\ p-ISSN: 2477-5967 e-ISSN: 2477-8443}

Dengan demikian, dalam penelitian ini peneliti bermaksud untuk mengembangkan modul dan RPP yang dapat membantu siswa dalam mengembangkan kemampuan pemecahan masalah matematis siswa pada materi PtLSV di kelas VII SMP.

\section{METODE PENELITIAN}

Metode penelitian yang digunakan dalam penelitian ini adalah penelitina dan pengembangan (research and development) yang direkomendasikan oleh Borg \& Gall (1983:775) yang dimodifikasi dengan model ADDIE yang memiliki lima fase utama yaitu Analysis, Design, Development, Implementation, dan Evaluation. Perangkat pembelajaran yang dikembangkan dalam penelitian ini meliputi Modul sebagai bahan ajar dan Rencana Pelaksanaan Pembelajaran (RPP) yang dibuat dengan mengacu pada tahapan modelProblem Based Learning (PBL) dan isi modul.

Pada tahap Analysis, kegiatan yang dilakukan adalah melakukan analisis kinerja, analisis kurikulum dan analisis kebutuhan guru dan siswa terhadap modul dan model pembelajaran. Pada tahap design, kegiatan yang dilakukan ada pembuatan draft awal modul dan RPP. Tahap keiga yaitu development, kegiatan yang dilakukan adalah proses validasi ahli dan validasi praktisi serta uji ketrebacaan terhadap isi modul. Setelah dinyatakan valid, dilanjutkan pada tahap Implementation, yaitu dengan mengujicobakan modul dan RPP yang dibuat ke dua sekolah. Kemudian di setiap sekolah dibandingkan hasil kemampuan pemecahan masalah antara yang menggunakan model PBL dan yang menggunakan moel pembelajaran langsung. pada tahapan yang terakhir yaitu Evaluation, kegiatan yang dilakukan adalah menganalisis kelayaan modul yang dilihat dri segi kevalidan, kepraktisan dan kefektifan.

Selain melihat kelayakan modul, dalam penelitian ini juga akan dianalsisi secara kuantitatif perbedaan peningkatan kemampuan pemecahan masalah matematis siswa antara yang menggunakan modul PBL (sebagai kelas eksperimen) dan kelas yang menggunakan model pembelajaran langsung (sebgai kelas kontrol), yang dalam penlitian ini keduanya menggunakan modul yang sama sebagai bahan ajar. Pada tahap implementation digunakan desain penelitian seperti pada Tabel I berikut:

Tabel I

Desain Pretest-Posttest Control Group

\begin{tabular}{ccc}
\hline Pre-test & Perlakuan & Post-test \\
\hline $\mathrm{O}_{1}$ & $\mathrm{X}_{1}$ & $\mathrm{O}_{2}$ \\
$\mathrm{O}_{1}$ & $\mathrm{X}_{2}$ & $\mathrm{O}_{2}$ \\
\hline
\end{tabular}

Keterangan:

$\mathrm{O}_{1}=$ Pretest $\quad \mathrm{O}_{2} \quad=$ Posttest

$\mathrm{X}_{1}=$ Perlakuan dengan menerapkan model PBL berbantuan modul

$\mathrm{X}_{2}=$ Perlakuan dengan menerapkan model pembelajaran langsung dengan pendekatan saintifik berbantuan modul

Untuk meganalisis perbedaan peningkatan anatara kelas eksperimen dan kelas control digunakan langkah sebagai berikut ; (1) untuk mengetahui apakah terdapat perbedaan kemampuan pemecahan masalah matematis siswa pada materi PtLSV sebelum dan sesudah diterapkannya model (PBL atau pembelajaran langsung) berbantuan modul digunakan uji perbedaan rerata menggunakan uji statistic Paired t-test dengan menggunakan SPSS versi 22.0; (2) Untuk mengetahui apakah terdapat perbedaan peningkatan kemampuan pemecahan masalah matematis siswa antara kelas yang menggunakan model PBL berbantuan modul dan kelas yang menggunakan model pembelajaran langsung dengan pendekatan saintifik berbantuan modul pada materi PtLsV kelas VII, digunakan rumus $N-$ gain, dilanjutkan dengan pengujian normalitas skor indeks gain dengan menggunakan SPSS versi 22.0, pengujian homoginitas dengan uji Levene menggunakan SPSS versi 22.0 dan uji perbedaan rerata terhadap skor indeks gain dengan uji statistic dua sample independent.

\section{HASIL DAN PEMBAHASAN}

\section{Kelayakan Modul dan RPP}

Modul berbasis masalah dan RPP dibuat untuk mengembangkan pemecahan masalah matematis siswa pada materi PtLSV. Pada Tahap analysis ditemukan bahwa dalam pembelajaran matematika yang terjadi di SMP $\mathrm{N} 2$ dan SMP $\mathrm{N} 2$ Singkawang, masih terbatas dan jarang 
digunakannya bahan ajar modul matematika dalam proses pembelajaran, serta model pembelajaran yang digunakan masih didominasi oleh peran guru. Berdasarkan wawancara dengan guru mata pelajaran matematika dan siswa diperoleh informasi bahwa guru belum pernah menggunakan bahan ajar berupa modul berbasis masalah, guru dan siswa juga sangat setuju bahwa bahan ajar modul matematika berbasis masalah perlu dikembangkan. Berdasarkan analisis secara konseptual dan temuan d ilapangan tersebut disimpulkan bahwa diperlukan suatu modul yang dapat digunakan untuk membantu siswa memahami materi dan mengembangkan kemampuan pemecahan masalah, serta untuk memfasilitasi pelaksanaannya diperlukan suatu model pembelajaran. Maka dari itu, struktur Isi modul dirancang disesuaikan dengan tahapan pada model PBL, dan selanjutnya RPP juga dirancang sedemikian sehinnga kegaiatan pembelajarannya tidak hanya mengeacu pada tahapan PBL itu sendiri, tapi juga mengacu pada struktur isi modul.

Modul dan RPP yang dihasilkan dalam penelitian ini dinyatakan layak digunakan karena telah memenuhi kriteria valid, praktis dan efektif. Kevalidan dilihat berdasarkan validasi ahli oleh dua dosen matematika dan validasi praktisi oleh dua guru matematika. Beberapa masukan atau saran dijadikan dasar untuk merevisi modul dan RPP, diantaranya: 1) setiap isian yang ada pada modul diberi tanda; 2) pada setiap penyelesaian masalah siswa diarahkan dengan pertanyaan yang mengacu pada indikator kemampuan pemecahan masalah; 3) pada kolom kesimpulan akhir dari masalah, siswa diarahkan untuk memberikan kesimpulan dengan car sendiri yang dianggap benar; 4) Langkah pada setiap kegiatan pembelajaran di RPP (baik eksperimen maupun control) harus jelas dan diberi keterangan apa yang dilakukan; 5) Isi kegiatan RPP dibuat mengacu pada modul, sehingga setiap kegiatan yang mengarah pada penggunaan modul sebaiknya disertai halalaman modul. Berikut hasil validasi kelayakan modul.
Tabel II

Hasil Validasi Kelayakan Modul dan RPP

\begin{tabular}{ccc}
\hline Validator & $\begin{array}{c}\text { Skor } \\
\text { Modul }\end{array}$ & $\begin{array}{c}\text { Skor } \\
\text { RPP }\end{array}$ \\
\hline Ahli 1 & 4,5 & 4,8 \\
& (Sangat Valid) & (Sangat Valid) \\
Ahli 2 & 4,7 & 4,9 \\
& (Sangat Valid) & (Sangat Valid) \\
Praktisi 1 & 4,8 & 4,9 \\
& (Sangat Valid) & (Sangat Valid) \\
Praktisi 2 & 4,7 & 4,8 \\
& (Sangat Valid) & (Sangat Valid) \\
\hline Kepraktisan & modul dan & RPP
\end{tabular}

dikembangkan dilihat berdasarkan dua hal yaitu respon siswa setelah belajar menggunakan modul dan keterlaksanaan RPP selama proses pembelajaran. Dari hasil angket respon siswa terhadap modul diperoleh rata-rata persentase skor sebesar 85\% (SMP N 2 Singkawang) dan $88 \%$ (SMP N 7 Singkawang) dari 10 pertanyaan yang berarti respon siswa berada dalam kategori sangat baik. Dari pernyataan yang ada pada angket mennjukkan bahwa siswa sangat setuju bahwa modul pembelajaran yang digunakan menarik, menantang untuk dikerjakan, mudah dipahami, mendukung proses pemecahan masalah, mendukung siswa untuk menguasai materi yang sedang dipelajari, sertadapat mendorong siswa untuk berperan aktif dalam pembelajaran. Untuk keterlaksanaan pembelajaran diamati melalui serangkaian kegiatan pada RPP yang dilakukan guru dan siswa dengan mengacu pada tahapan PBL selama tiga pertemuan diperoleh persentase $\begin{array}{lllll}\text { keterlaksanaan sebesar } & 98 \% & \text { (SMP } & \text { N } & 2\end{array}$ Singkawang) dan 95\% (SMP N 7 Singkawang) artinya hampir semua aspek yang diamati pada RPP mendapat point maksimal yaitu 5 (sangat Baik).

Keefektivan modul dan RPP dilihat berdasarkan ketuntasan hasil belajar siswa setelah proses pembelajaran. Hasil belajar yang dimaksud adalah nilai posttest siswa. Nilai posttest siswa di kelas eksperimen (kelas yang mendapat pembelajaran dengan model PBL dan menggunakan modul) dievaluasi dan dianalisis secara kuantitatif dan diperoleh bahwa terdapat ketuntasan secara klasikal. Jumlah siswa yang tuntas dan jumlah siswa yang tidak tuntas dapat dilihat pada Tabel berikut. 
Tabel III

Rekapitulasi Ketuntasan Hasil Belajar Siswa

\begin{tabular}{lcccc}
\hline \multirow{2}{*}{ Kategori } & \multicolumn{2}{c}{ SMP N 2 Skw } & \multicolumn{2}{c}{ SMP N 7 Skw } \\
\cline { 2 - 5 } & Jumlah & $\%$ & Jumlah & $\%$ \\
\hline Tuntas & 23 & $72 \%$ & 22 & $71 \%$ \\
Tidak Tuntas & 9 & $28 \%$ & 9 & $29 \%$ \\
Jumlah & 32 & $100 \%$ & 31 & $100 \%$ \\
\hline
\end{tabular}

Berdasarkan Tabel III di atas diketahui bahwa hasil belajar siswa di kelas eksperimen pada dua sekolah jumlah siswa yang tuntas lebih banyak dari jumlah siswa yang tidak tuntas, yaitu mencapai persentase lebih dari $70 \%$. Hal ini menunjukkan bahwa penggunaan modul sebagai bahan ajar dan RPP sebagai panduan untuk melaksanakan proses pembelajaran efektif untuk digunakan.

Berdasarkan tahapan pengembangan di atas, dimulai dari tahap analysis sampai tahap evaluation dapat disimpulkan bahwa modul dan RPP yang dikembangkan telah layak dan dapat digunakan dalam proses pembelajaran, serta dapat dijadikan sebagai alat untuk mengembangkan kemampuan pemecahan masalah matematis siswa.

2. Kemampuan Pemecahan Masalah Matematis Siswa di SMP N 2 Singkawang

Pada tahap Implementation, modul dan RPP yang dikembangkan diujicobakan ke SMP N 2 Singkawang. Dari hasil uji coba ini diperoleh nilai pretest dan nilai posttest. Hasil tersebut dievaluasi dan dianalisis secara kuantitatif untuk melihat perbedaan peningkatan kemampuan pemecahan masalah matematis siswa antara kelas eksperimen (kelas yang menggunakan model PBL berbatuan modul) dan kelas kontrol (kelas yang menggunakan model pembelajaran langsung dengan pendekatan saintifik berbantuan modul). Berikut rekapitulasinya:

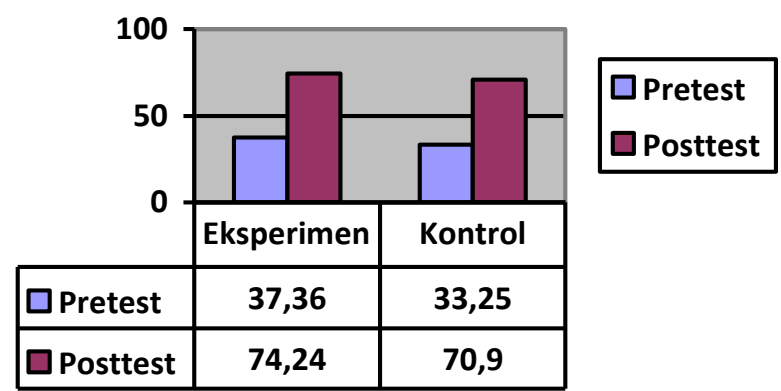

Gambar 1. Rekapitulasi Rata-rata Nilai Pretest dan Posttest di SMP Negeri 2 Singkawang

Berdasarkan Gambar 1 hasil pretest dan posttest di SMP N 2 Singkawang di atas, dapat diketahui bahwa nilai pretest dan posttest siswa mengalami perkembangan. Hal itu tampak dari hasil posttest yang lebih baik (nilainya lebih tinggi) dibandingkan hasil pretestnya. Hal tersebut diperkuat dari hasil uji perbedaan rata-rata nilai pretest dan nilai posttest pada masing-masing kelas (eksperimen dan kontrol). Berikut rangkuman hasil uji normalitas dan uji $t$-Test Paired.

Tabel IV

Rekapitulasi Hasil Uji Kolmogorov-Smirnov dan Uji $t$-Test Paired (SMP N 2 Singkawang)

\begin{tabular}{ccccc}
\hline Nilai & \multicolumn{2}{c}{$\begin{array}{c}\text { Uji Kolmogorov- } \\
\text { Smirnov }\end{array}$} & Uji t-Test Paired \\
\hline & Eksperimen & Kontrol & Ekspeimen & Kontrol \\
\hline Pretest & 0,200 & 0,200 & 0,000 & 0,000 \\
Posttest & 0,200 & 0,200 & & \\
\hline
\end{tabular}

Berdasarkan uji normalitas data menggunakan Kolmogorov-Smirnov diperoleh nilai sig sebesar $0,200>0,05$, artinya data berdistribusi normal. Kemudian dilanjutkan dengan uji t-Test Paired dan diperoleh nilai (sig.2-tailed) sebesar 0,000 < 0,5 yang berarti $\mathrm{H}_{0}$ ditolak, $\mathrm{H}_{\mathrm{a}}$ diterima, artinya terdapat perbedaan kemampuan pemecahan masalah matematis siswa antara sebelum dan sesudah diterapkan pembelajaran. 


\section{A - - - Jurnal Pendidikan Matematika Indonesia \\ Volum 3 Nomor 2 bulan September 2018 Page 66 - 73 \\ p-ISSN: 2477-5967 e-ISSN: 2477-8443}

Adanya perbedaan antara nilai pretest dan posttest mennjukkan adanya peningkatan. Ratarata nilai $\mathrm{N}$-gain kemampuan pemecahan matematis siswa di kelas eksperimen sebesar 0,59 (kategori sedang) dan di kelas kontrol sebesar 0,55 (kategori sedang). Berikut rangkuman hasil perhitungan N-gain Kemampuan Pemecahan masalah matematis siswa di kelas eksperimen dan kelas kontrol.

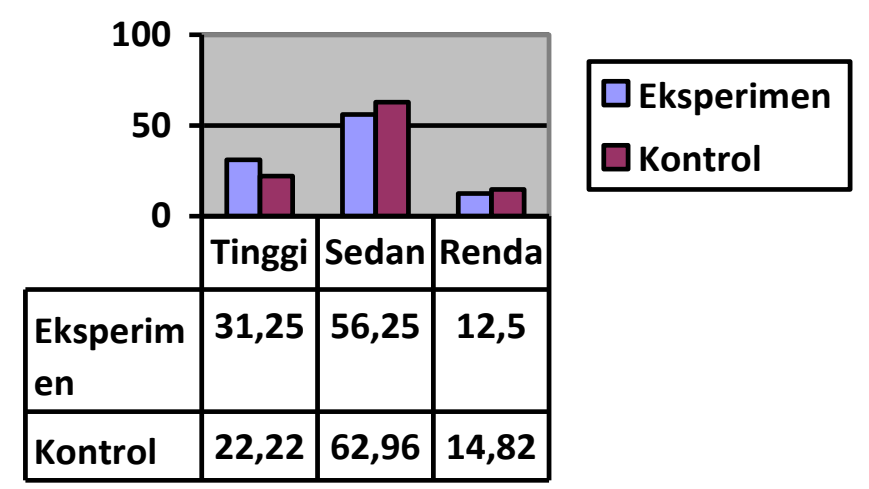

Gambar 2. Rangkuman Hasil Perhitungan N-Gain pada Tiap Kategori di SMP N 2 Singkawang

Jika dilihat berdasarkan rata-rata $\mathrm{N}$-gain yang sama-sama berada pada kategori sedang dengan selisih 0,04 dan jumlah siswa pada tiap kategori NGain di kelas eksperimen dan kontrol yang tidak jauh berbeda, menunjukkan bahwa peningkatan kemampuan pemecahan masalah matematis siswa pada kedua kelas tidak berbeda.

Tabel V

Rekapitulasi Hasil Uji Kolmogorov-Smirnov,Uji Levene, dan Uji Independent T-Test (SMP N 2 Singkawang)

\begin{tabular}{cccc}
\hline $\begin{array}{c}\text { Nilai N- } \\
\text { Gain }\end{array}$ & $\begin{array}{c}\mathrm{Uji} \\
\text { Kolmogorov- } \\
\text { Smirnov }\end{array}$ & $\begin{array}{c}\mathrm{UJi} \\
\text { Levene }\end{array}$ & $\begin{array}{c}\mathrm{Uji} \\
\text { Independent } \\
\text { T-test }\end{array}$ \\
\hline $\begin{array}{c}\text { Eksperimen } \\
\text { Kontrol }\end{array}$ & 0,200 & 0,494 & 0,539 \\
\hline
\end{tabular}

Berdasarkan Tabel $\mathrm{V}$ di atas diketahui bahwa data N-Gain di kelas eksperimen berdistribusi normal. Hasil uji Levene menunjukkan nilai sig. sebesar 0,494>0,05 yang berarti $\mathrm{H}_{0}$ diterima, artinya variansi kedua populasi data peningkatan kemampuan pemecahan masalah matematis kelas eksperimen dan kontrol adalah homogen. Selanjutnya dari hasil uji independent T-test diperoleh nilai sig (2 tailed) sebesar 0,539>0,05 yang berarti $\mathrm{H}_{0}$ diterima, artinya tidak terdapat perbedaan peningkatan kemampuan pemecahan masalah matematis siswa antara kelas eksperimen dan kelas control.

3. Kemampuan Pemecahan Masalah Matematis Siswa di SMP N 7 Singkawang

Modul dan RPP yang dikembangkan juga diujicobakan ke SMP N 7 Singkawang. Dari hasil uji coba ini diperoleh nilai pretest dan nilai posttest. Hasil tersebut dievaluasi dan dianalisis secara kuantitatif untuk melihat perbedaan peningkatan kemampuan pemecahan masalah matematis siswa antara kelas eksperimen (kelas yang menggunakan model PBL berbatuan modul) dan kelas kontrol (kelas yang menggunakan model pembelajaran langsung dengan pendekatan saintifik berbantuan modul). Berikut rekapitulasinya:

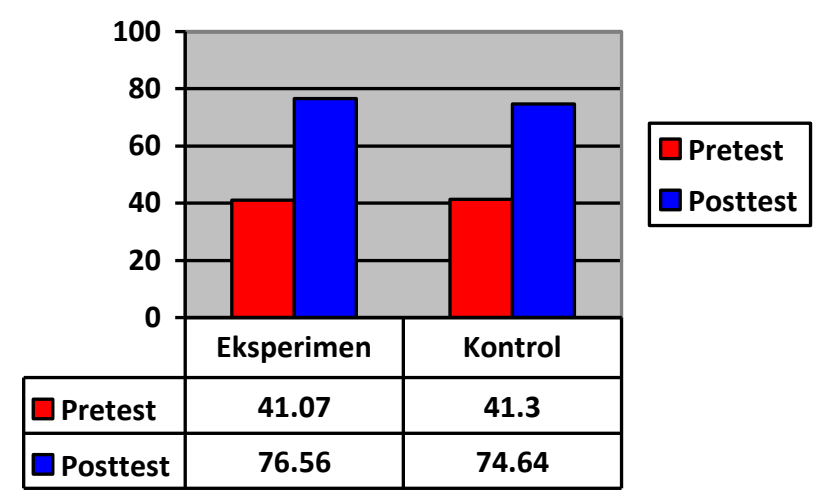

Gambar 3. Rekapitulasi Rata-rata Nilai Pretest dan Posttest di SMP Negeri 7 Singkawang

Berdasarkan Gambar 1 hasil pretest dan posttest di SMP N 7 Singkawang di atas, dapat diketahui bahwa nilai pretest dan posttest siswa mengalami perkembangan. Hal itu tampak dari hasil posttest yang lebih baik (nilainya lebih tinggi) dibandingkan hasil pretestnya. Hal tersebut diperkuat dari hasil uji perbedaan rata-rata nilai pretest dan nilai posttest pada masing-masing kelas (eksperimen dan kontrol). Berikut rangkuman hasil uji normalitas dan uji $t$-Test Paired. 


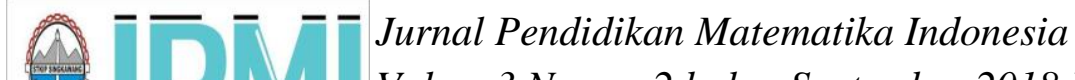 \\ Volum 3 Nomor 2 bulan September 2018 Page 66 - 73 \\ p-ISSN: 2477-5967 e-ISSN: 2477-8443}

Tabel VI

Rekapitulasi Hasil Uji Kolmogorov-Smirnov dan Uji $t$-Test Paired (SMP N 7 Singkawang)

\begin{tabular}{ccccc}
\hline Nilai & \multicolumn{2}{c}{$\begin{array}{c}\text { Uji Kolmogorov- } \\
\text { Smirnov }\end{array}$} & Uji t-Test Paired \\
\hline & Eksperimen & Kontrol & Ekspeimen & Kontrol \\
\hline Pretest & 0,200 & 0,200 & 0,000 & 0,000 \\
Posttest & 0,200 & 0,200 & & \\
\hline
\end{tabular}

Sama halnya seperti di SMP N 2 Singkawang nilai pretest dan posttest pada kelas eksperimen dan control berdistribusi normal dan berdasarkan uji $t$-Test Paired juga emnunjukkan bahwa terdapat perbedaan kemampuan pemecahan masalah matematis siswa antara sebelum dan sesudah diterapkan pembelajaran.

Rata-rata nilai $\mathrm{N}$-gain kemampuan pemecahan matematis siswa di kelas eksperimen sebesar 0,63 (kategori sedang) dan di kelas kontrol sebesar 0,58 (kategori sedang). Berikut rangkuman hasil perhitungan $\mathrm{N}$-gain Kemampuan Pemecahan masalah matematis siswa di kelas eksperimen dan kelas kontrol.

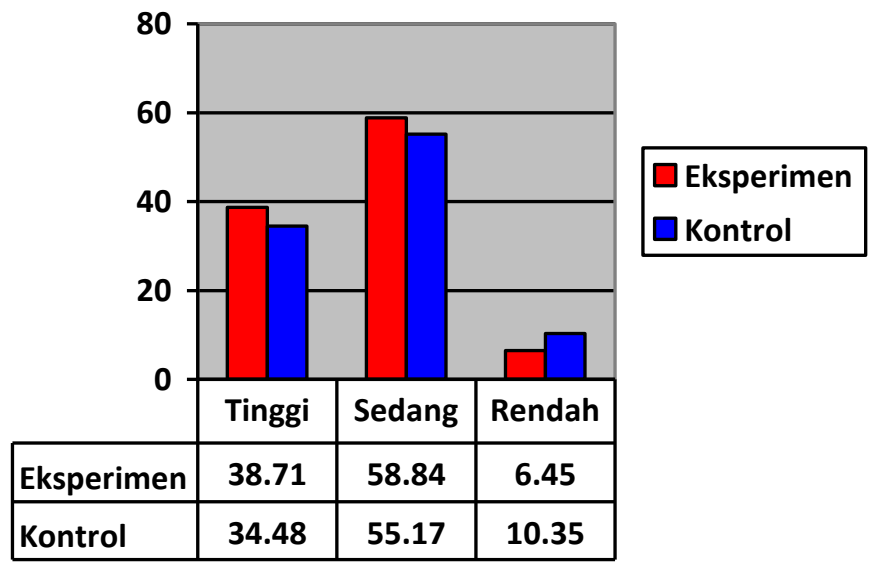

Gambar 4. Rangkuman Hasil Perhitungan N-Gain pada Tiap Kategori di SMP Negeri 7 Singkawang

Seperti halnya di SMP N 2 Singkawang ratarata $\mathrm{N}$-gain sama-sama berada pada kategori sedang dengan selisih 0,05 dan jumlah siswa pada tiap kategori N-Gain di kelas eksperimen dan kontrol yang tidak jauh berbeda, menunjukkan bahwa peningkatan kemampuan pemecahan masalah matematis siswa pada kedua kelas tidak berbeda. Hal ini juga diperkuat dengan uji independent t-test
Tabel VII

Rekapitulasi Hasil Uji Kolmogorov-Smirnov,Uji Levene, dan Uji Independent T-Test (SMP N 7 Singkawang)

\begin{tabular}{cccc}
\hline $\begin{array}{c}\text { Nilai N- } \\
\text { Gain }\end{array}$ & $\begin{array}{c}\text { Uji } \\
\text { Kolmogorov- } \\
\text { Smirnov }\end{array}$ & $\begin{array}{c}\mathrm{UJi} \\
\text { Levene }\end{array}$ & $\begin{array}{c}\mathrm{Uji} \\
\text { Independent } \\
\text { T-test }\end{array}$ \\
\hline $\begin{array}{c}\text { Eksperimen } \\
\text { Kontrol }\end{array}$ & 0,200 & 0,143 & 0,328 \\
\hline
\end{tabular}

Berdasarkan Tabel VII di atas diketahui bahwa data N-Gain di kelas eksperimen berdistribusi normal. Hasil uji Levene menunjukkan nilai sig. sebesar $0,143>0,05$ yang berarti $\mathrm{H}_{0}$ diterima, artinya variansi kedua populasi data peningkatan kemampuan pemecahan masalah matematis kelas eksperimen dan kontrol adalah homogen. Selanjutnya dari hasil uji independent T-test diperoleh nilai sig (2 tailed) sebesar 0,328 >0,05 yang berarti $\mathrm{H}_{0}$ diterima, artinya tidak terdapat perbedaan peningkatan kemampuan pemecahan masalah matematis siswa antara kelas eksperimen dan kelas kontrol.

Terdapat perbedaan yang signifikan antara sebelum dan sesudah diterapkannya model PBL berbantuan modul disebabkan oleh kesesuaian antara tahapan proses berfikir siswa dengan tahapan kegiatan pembelajaran dengan PBL. Sebagai contoh pada tahapan pertama PBL, hal yang dilakukan adalah orientasi siswa pada masalah (ada pada modul). Kegiatan yang dilakukan pada tahap ini adalah siswa diberikan beberapa masalah nyata kemudian siswa diminta membaca dan memahami apa yang dapat diketahui dan menjadi permasalahan pada masalah tersebut, sehingga siswa tidak secara langsung diberi materi baik itu pengertian maupun rumus atau cara yang digunakan, melainkan beberapa contoh masalah kontekstual. Akibat dari proses ini membantu siswa mengkonstruksi pemahaman terhadap materi yang akan di pelajari dengan memberikan masalah nyata ke masalah yang abstrak.

Tidak adanya perbedaan yang signifikan antara kelas eksperimen dan kelas kontrol disebabkan dua hal, yaitu:1) pembelajaran yang digunakan pada masing-masing kelas sama-sama mengarah pada pendekatan saintifik, sehingga pada pembelajaran langsung peran serta guru harus diimbangi oleh kegiatan siswa; 2) penggunaan modul yang sama di kedua kelas membantu menuntun dan 


\section{A - - - Jurnal Pendidikan Matematika Indonesia \\ Volum 3 Nomor 2 bulan September 2018 Page 66 - 73 \\ p-ISSN: 2477-5967 e-ISSN: 2477-8443}

mengarahkan siswa untuk memecahkan masalah, hal ini membantu siswa berfikir secara terurut dan sistematis sehingga dapat memecahkan masalah.

\section{IV.KESIMPULAN}

\section{KESIMPULAN}

Dengan memperhatikan hasil penelitian dan pembahasan yang telah peneliti paparkan, maka secara umum dapat disimpulkan bahwa modul dan RPP yang dikembangkan layak digunakan dan efektif dalam meningkatkan kemampuan pemecahan masalah matematis siswa pada materi PtLSV baik di SMP Negeri 2 Singkawang maupun di SMP Negeri 7 Singkawang. Sesuai dengan sub-sub masalah penelitian, secara khusus dapat disimpulkan beberapa hal sebagai berikut.

1. Modul berbasis masalah dan RPP yang dikembangkan layak digunakan untuk mengembangkan kemampuan pemecahan masalah matematis siswa, karena telah memenuhi kriteria valid, praktis dan efektif.

2. Tidak terdapat perbedaan peningkatan kemampuan pemecahan masalah matematis siswa pada materi PtLSV antara kelas yang menggunakan model PBL dan kelas yang menggunakan model pembelajaran langsung dengan pendekatan saintifik berbantuan modul di SMP Negeri 2 Singkawang.

3. Tidak Terdapat perbedaan peningkatan kemampuan pemecahan masalah matematis siswa pada materi PtLSV antara kelas yang menggunakan model PBL dan kelas yang menggunakan model pembelajaran langsung dengan pendekatan saintifik berbantuan modul di SMP Negeri 7 Singkawang.

\section{SARAN}

1. Model PBL berbantuan modul dapat menjadi satu diantara alternatif dalam pembelajaran matematika untuk mengembangkan kemampuan pemecahan masalah matematis siswa.

2. Penyajian materi dan permasalahan yang ada di dalam modul dapat dikembangkan kembali sesuai dengan kebutuhan pembelajaran.
3. Bagi guru matematika modul matematika berbasis masalah dapat dijadikan sebagai bahan ajar pendamping dalam proses pembelajaran matematika untuk meningkatkan kemampuan pemecahan masalah matematis siswa

\section{DAFTAR PUSTAKA}

Badu, Syamsu Qomar. (2014). Mengembangkan Kemampuan Komunikasi dan Pemecahan Maslah Matematika Siswa SMA Melalui Model Pembelajaran Berdasarkan Masalah. Diakses 19 September 2015

Borg and Gall. 1983. Education Research. New York : Longman.

Citroresmi, N., Sugiatno,S.,\&Suratman,D. 2016. Pengembangan Modul Berbasis Masalah untuk Meningkatkan Kemampuan Pemecahan Masalah dan Berpikir Kreatif Matematis Siswa. Tesis. Jurnal Pendidikan dan Pembelajaran, volume 5(4). 2016.

Daryanto. 2013. Menyusun Modul Bahan Ajar Untuk Persiapan Guru Dalam Mengajar. Jogjakarta : Gava Media.

Hamdani. 2011. Strategi Belajar Mengajar. Bandung: Pustaka Setia

Majid A.2011. Perencanaan Pembelajaran Mengembangkan Standar KompetensI Guru. Bandung : PT. Remaja Rosdakarya.

Mariyam dan Wahyuni, R. 2016. Pengembangan Kemampuan Penalaran Matematis Siswa Melalui Problem Centered Learning pada Materi Peluang (Studi Eksperimen di Kelas VIII SMP N 6 Singkawang. Jurnal Pendidikan Matematika Indonesia Volum 1 Nomor 2 Bulan September 2016.

Mulyasa. 2009. Kurikulum yang Disempurnakan Pengembangan Standar Kompetensi dan Kompetensi Dasar. Bandung: Remaja Rosdakarya

National Council of Teacher of Mathematics. 2000. Principles and Standards for School Mathematics

OECD. 2016. Programe For International Student Assessment (PISA) Result From PISA 2015.

Sumarmo, U. 2014. Penilaian Pembelajaran Matematika. Cimahi : Refika Aditama

Scolastika, dkk. 2014. The Effectivennes Learning by PBL Assisted Mathematics Pop Up Book Againts The Spatial Abilty in Grade VIII on Geometry Subject Matery. International Journal Education and Research.

TIMSS. 2011.TIMSS 2011 International Result in Mathematics. USA: TIMSS \& PIRLS International Study Center and IEA 